\title{
Infrared thermography and feeding behavior of lambs fed increasing levels of safflower grains
}

\section{Termografia infravermelha e comportamento alimentar de ovinos alimentados com} níveis crescentes de grãos de cártamo

Ferreira, Mateus Silva ${ }^{1}$

https://orcid.org/0000-0002-5196-696X

Goes, Rafael Henrique de Tonissi e

Buschinelli de ${ }^{2}$

https://orcid.org/0000-0002-4744-0367

Martinez, Antonio Campanha ${ }^{1}$

https://orcid.org/0000-0002-9002-5388

Gandra, Jefferson Rodrigues ${ }^{4}$

https://orcid.org/0000-0002-3287-8737

\author{
Gonçales Junior, Walter Antonio \\ https://orcid.org/0000-0003-0162-8177 \\ Bega, Amanda Maristela ${ }^{1}$ \\ https://orcid.org/ 0000-0002-2016-8797 \\ Silva, Luan Sitó da ${ }^{1}$ \\ https://orcid.org/0000-0002-2493-1067 \\ Paz, Jessica Priscila da ${ }^{1}$ \\ https://orcid.org/0000-0003-2164-2531
}

\footnotetext{
${ }^{1}$ Universidade Estadual Paulista - Unesp, Faculdade de Ciências Agrarias e Veterinárias - FCAV, Via de Acesso Professor Paulo Donato Castelane Castellane S/N - Vila Industrial, 14884-900, Jaboticabla/SP, Brasil

${ }^{2}$ Universidade Federal da Grande Dourados -UFGD, R. João Rosa Góes, 1761 - Vila Progresso, Dourados - MS, 79825-070, Brasil

${ }^{3}$ Universidade Estadual de Maringá, campus de Umuarama, Av. Colombo, 5790 - Zona 7, Maringá - PR, 87020-900, Brasil

${ }^{4}$ Universidade Federal do Sul e Sudeste do Pará-UNIFESSPA, Folha 31, Quadra 07, Lote Especial, s/n. ${ }^{\circ}$ - Nova Marabá, Marabá - PA, 68507-590, Brasil

* Corresponding author: rafaelgoes@ufgd.edu.br
}

\begin{abstract}
The objective was to evaluate the feeding behavior, physiological responses, and rumen heat emission of lambs fed with safflower grains. Eighteen lambs were randomly distributed in a completely randomized design. Safflower grain was added to the diets in the proportions of $0.0 ; 7.5$ and $15 \%$. The safflower grain did not change the patterns of eating, leisure, or rumination; however, it improved the efficiency of NDF ingestion, by $26 \%$. The head temperature decreased by $1.5^{\circ} \mathrm{C}$ to include $7.5 \%$ safflower; and the rectal temperature decreased quadratically with the addition of safflower $\left(39.5\right.$ and. $\left.39.08^{\circ} \mathrm{C}\right)$. There was a linear trend of decreasing head temperature as the inclusion of safflower increased. The temperature of the eyeball decreased by $1.1^{\circ} \mathrm{C}$ when $7.5 \%$ of safflower DM was added to the diet and increased by $0.6^{\circ} \mathrm{C}$ when a $15 \%$ safflower was added. The ruminal temperature increased linearly for the addition of safflower $\left(1.8^{\circ} \mathrm{C}\right)$. Safflower
\end{abstract}


improves the efficiency of the use of NDF and the inclusion of $15 \%$ safflower can be used without effects on ingestive behavior. The head, eye, and left flank areas can be used; however, the left flank appears to be the best region for this type of study. Infrared thermography can be useful as a non-invasive assessment of lambs' diets.

Keywords: ruminal heat emission, ruminal temperature, oilseeds, PUFA, animal behavior

\section{RESUMO}

Objetivou-se avaliar o comportamento alimentar, respostas fisiológicas e emissão de calor ruminal, de cordeiros alimentados com grãos de cártamo. Dezoito cordeiros foram distribuídos aleatoriamente em delineamento inteiramente casualisado. $\mathrm{O}$ grão de cártamo foi adicionado as dietas nas proporções de 0,$0 ; 7,5$ e 15\%. O grão de cártamo não alterou os padrões de alimentação, ócio ou ruminação; porém melhorou a eficiência de ingestão da FDN, em $26 \%$. A temperatura da cabeça reduziu $1,5^{\circ} \mathrm{C}$ para a inclusão de $7,5 \%$ de cártamo; e a temperatura retal diminuiu quadraticamente com a adição de cártamo $(39,5$ vs. $39,08^{\circ} \mathrm{C}$ ). Houve uma tendência linear de diminuição da temperatura da cabeça à medida que a inclusão de cártamo aumentou. A temperatura do globo ocular diminuiu $1,1^{\circ} \mathrm{C}$ quando $7,5 \%$ de MS de cártamo foi adicionado na dieta e voltou a aumentar $0,6^{\circ} \mathrm{C}$ quando $15 \%$ de cártamo foi adicionado. A temperatura ruminal aumentou linearmente para a adição de cártamo $\left(1,8^{\circ} \mathrm{C}\right)$. $\mathrm{O}$ cártamo melhora a eficiência de utilização da FDN e a inclusão de $15 \%$ de cártamo pode ser utilizado sem efeitos sobre o comportamento ingestivo. As áreas da cabeça, do olho e flanco esquerdo podem ser usadas, no entanto, o flanco esquerdo parece ser a melhor região para esse tipo de estudo. A termografia infravermelha pode ser útil como avaliação não invasiva de dietas em cordeiros.

Palavras chaves: emissão de calor ruminal, temperatura ruminal, oleaginosas, PUFA, comportamento animal

\section{INTRODUCTION}

Animal welfare has been showing prominence in the most diverse fields in animal production and also in scientific research in the area, with these noninvasive techniques and equipment that value animal comfort and well-being are used.

Infrared thermography is a non-invasive technique of thermal body mapping, which uses images to measure changes in temperature generated by heat exchange or loss, emitted by the body surface (Roberto and Souza, 2014; McManus et al., 2016). These images are listed as measures to quantify the impact of environmental factors, promoting animal health and comfort (Chacur et al., 2016, Roberto and Souza, 2014).

With the process of intensification in animal production, diets with a high concentration of concentrate are becoming increasingly common to meet the nutritional needs of animals and explore the potential in meat production. The excess of fast fermenting carbohydrates increases ruminal heat synthesis and changes the ratio of the main substrates from fermentation, influencing the animals' physiological responses (Araki et al., 2018).

The inclusion of polyunsaturated fatty acids (PUFA) from oilseeds can reduce the heat emission from the synthesis of enteric methane, and as a consequence, 
the production of ruminal heat (Beauchemin et al., 2009). Safflower (Carthamus tinctorius) is an oilseed of Asian origin that contains 14 to $15 \%$ crude protein, 32 to $40 \%$ g crude fiber, and 27 to $30 \%$ g oil based on a dry matter (Gecgel et al., 2007), being rich in polyunsaturated fatty acids, with linoleic acid (70 to $87 \%$ ) as its main component (Coşge and Gürbüz, 2007).

The main hypothesis of this work would be that the inclusion of safflower grain in diets would reduce the fermentation caused by non-fibrous carbohydrates, thus decreasing the ruminal heat emission and the physiological responses of the animals, without affecting the ingestive behavior. Therefore, the objective of this study was to evaluate ingestive behavior, physiological responses, and rumen heat emission through the use of infrared thermography in lambs fed with increasing levels of safflower grains.

\section{MATERIAL AND METHODS}

All experimental procedures were performed according to ethical standards, approved by the Institutional Committee for Animal Experimentation at the Federal University of Grande Dourados (Protocol number CEUA021/2012). The experiment was carried out in the Animal Reproduction sector, at the State University of Maringá, Umuarama campus, Paraná, Brazil, between the months of May and June 2016.

Eighteen (18) lambs $1 / 2$ blood Suffolk and $1 / 2$ Ile de France, non-castrated males $(17.9 \pm 1.8 \mathrm{~kg}$ body weight and 6 months old) were weighed individually, dewormed, and housed in collective pens (2 animals/pen) with floor concrete, covered with ceramic tile and equipped with drinking fountains and feeders. The animals were randomly distributed in a completely randomized design, in three treatments, six repetitions: Control group (C0) (without safflower inclusion); (C7.5) inclusion of $7.5 \%$ safflower grains, and (C15) inclusion of $15 \%$ safflower grains.

The experimental diets were formulated to be isoenergetic and provide gains of $0.25 \mathrm{~kg} /$ day (NRC, 2007) (Table 1). The animals were fed twice a day, ad libitum (8 am and $4 \mathrm{pm}$ ), and free access to water. The leftover feed in the trough was removed daily, weighed, and dried in the forced ventilation oven for 72 hours temperature of $55^{\circ} \mathrm{C}$ to calculate the dry matter consumption (DMC).

The safflower grain used in the diets showed $90 \%$ dry matter (DM), 33\% of ether extract (EE), $16 \%$ of crude protein (CP), 44\% of neutral detergent fiber (NDF), $32 \%$ fiber in acid detergent (FDA) and $2.8 \%$ ash. The animals were submitted to the experimental period of 62 days plus the period of adaptation to the facilities, diet, and management for 14 days, totaling 76 experimental days. 
Table 1. The proportion of ingredients and chemical composition of experimental diets

\begin{tabular}{|c|c|c|c|}
\hline \multirow{2}{*}{ Ingredients (\%DM) } & \multicolumn{3}{|c|}{ Levels of Inclusion $^{1}$} \\
\hline & 0.0 & 7.5 & 15 \\
\hline Corn & 59.00 & 54.40 & 49.80 \\
\hline Soybean meal & 16.00 & 13.10 & 10.20 \\
\hline Soybean grain & 0.00 & 7.50 & 15.00 \\
\hline Tifton-85 Hay & 20.00 & 20.00 & 20.00 \\
\hline Mineral blend ${ }^{2}$ & 5.00 & 5.00 & 5.00 \\
\hline \multicolumn{4}{|c|}{ Composition Bromatological (\%DM) } \\
\hline Crude protein & 14.46 & 13.98 & 13.49 \\
\hline Ether extract & 1.40 & 3.75 & 6.10 \\
\hline Neutral Detergent Fiber (NDF) & 22.96 & 25.45 & 27.95 \\
\hline NDF - bulky & 15.44 & 15.44 & 15.44 \\
\hline Fiber in acid detergent (FAD) & 12.43 & 14.35 & 16.26 \\
\hline Ashes & 1.39 & 1.67 & 1.86 \\
\hline Non-fibrous carbohydrates & 59.79 & 55.15 & 50.60 \\
\hline $\mathrm{EM}^{4}, \mathrm{Mcal} / \mathrm{kg}$ & 2.72 & 2.73 & 2.75 \\
\hline
\end{tabular}

On the last day of each experimental period, a previously trained team started collecting data on the animals' physiological responses, starting at 6:00 am. The start of taking the physiological variables started together with the feeding management of the animals to standardize the results of thermoregulation to Nutritionals. The rectal temperature (RT) was measured with the aid of a clinical thermometer inserted $3 \mathrm{~cm}$ in the rectum of the animal, the skin and head temperature with the aid of an infrared thermometer, and the respiratory rate measured as flank movements per minute counted for $15 \mathrm{~s}$ using a digital timer.

After collecting the physiological parameters, on the day 12,13 , and 14 of each experimental period. Before (0) and
$2,4,6$, and 8 hours after the morning feeding, the animals' infrared thermography was performed using a thermography camera. infrared (Testo ${ }^{\circledR}$ model 875-1i, Testo, Lenzkirch, BH, Germany). The dynamics of thermographic measurements were adjusted so that the interaction between thermoregulation and nutrition was the best possible. The day before the image collections, the animals were removed from the stalls, cleaned, and shorn in the flank region so that the skin's dirt and wool would not interfere with the images. Infrared thermography images were performed on the animal's eyes (eyeball), forehead, skin, and left flank (Figure 1) and at a distance of approximately $1 \mathrm{~m}$, according to Salles et al. (2016). The animals were removed 
from the stalls and positioned so that they would not impair the performance of the images. The images were collected before and every 2 hours after the first meal, to standardize the rumen fermentation time.

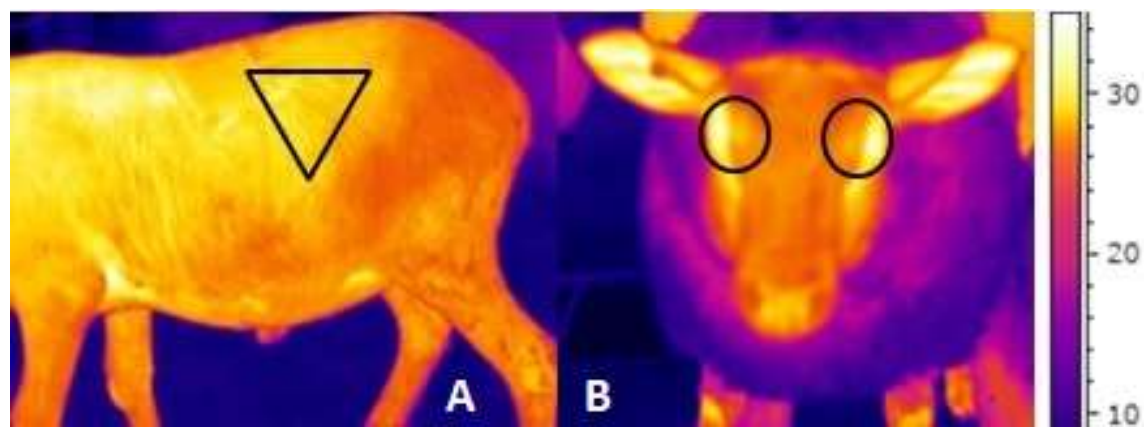

Figure 1. Image of infrared thermography on the flank (A) and frontal region (B) of lambs fed with safflower grains.

The environmental variables (temperature and relative humidity of the air) were collected daily using digital Thermo hygrometers positioned in three points of the shed (beginning, middle, and end). Environmental data were used to calculate the temperature and humidity index (THI) following the equation proposed by Mader et al. (2006).
Where $\mathrm{T}$ is the average temperature $\left({ }^{\circ} \mathrm{C}\right)$ and $\mathrm{RH}$ is the relative humidity (\%) (Figure 2):

$$
\begin{gathered}
T H I=((0.8 \times T+(R H / 100) \times(T \\
-14.4)+46.4))
\end{gathered}
$$




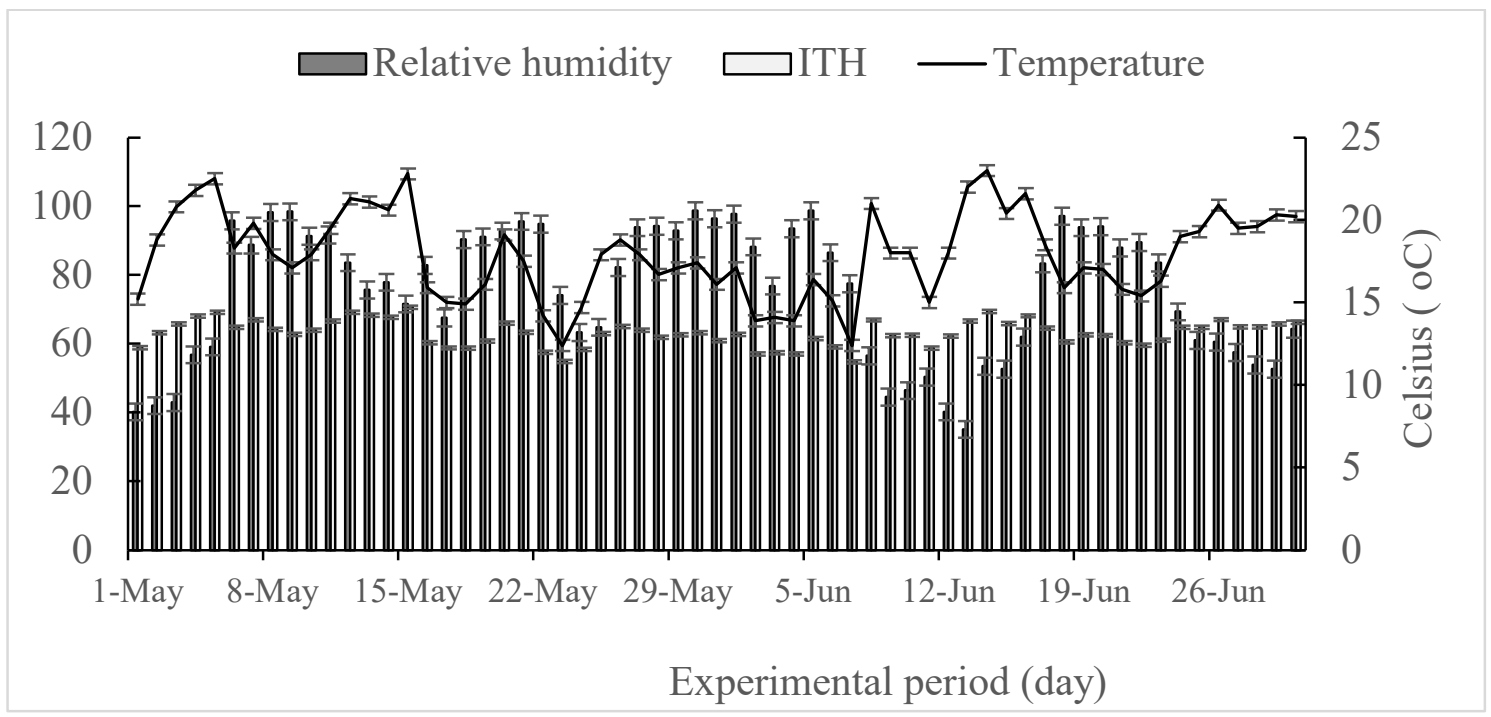

Figure 2. Daily measurements of average temperature, relative humidity, and temperature and humidity index during the experimental period

The feeding behavior of the animals was analyzed on day 30 and 31 experimental periods (Eustáquio Filho et al., 2014). The visual observation was quantified in a period of 24 hours and; the variables evaluated were the time spent feeding, ruminating, and idling each animal (Fischer et al., 1998). The visual assessment was carried out every five minutes by four previously trained observers, using a (turn-turn) system, strategically positioned so as not to disturb the animals, totaling 288 measurements per period. On the same day, the number of ruminations for bolus $(\mathrm{NRbl})$ and the bolus rumination time NRtm (sec/min) was observed, using a digital timer (Polli et al., 1996). To obtain the average values, ten cuds were observed in three periods of the day (10$12,14-16$, and 18-20 hour), counting the time and number of chews per cud per animal.

For the estimation of behavioral variables, feeding and rumination variables ( $\mathrm{min} / \mathrm{kg} \mathrm{DM}$ and NDFP), feeding efficiency (g DM and NDF/h), rumination efficiency ( $g$ DM and NDFP/bolus eg DM and NDFP/h), and average intake of dry matter (DM) and neutral detergent fiber corrected for ashes and proteins (NDFP) per feeding period, we consider the voluntary intake of DM and NDFP on the 15 at the day of each period and on the 30th and 31st day of the experiment, with the remains being computed on the 16 at the day of each period and the 31 and 32 at the day of the experiment.

The daily number of boluses was obtained by dividing the total rumination time (minutes) by the average time spent in the rumination of a bolus. The dry matter and NDF concentrations in each rumination bolus $(\mathrm{g})$ were obtained by dividing the amount of DM and NDF consumed (g/day) in 24 hours by the number of daily rumination boluses. The efficiency of feeding (EF) and rumination was obtained as follows:

$$
\begin{aligned}
\mathrm{EFDM} & =\mathrm{DMI} / \mathrm{TSF} \\
\mathrm{EFNDF} & =\mathrm{NDFI} / \mathrm{TSF}
\end{aligned}
$$

Where, Feed efficiency of EFDM (g DM consumed/h) and EFNDF ( $g$ NDF 
consumed/h); DMI (g) = daily dry matter intake; NDFI $(\mathrm{g})=$ daily NDF intake; $\mathrm{TSF}=$ time spent feeding every day.

$$
\text { RUDM= DMI/RUT }
$$

RUNDF $=$ INDFap/RUT

Where, RUDM (DM ruminating g/hour); RUFDN (FDN ruminating $\mathrm{g} /$ hour) = rumination efficiency e RUT (hour/day) $=$ rumination time; INDFap = neutral detergent fiber intake corrected for ash and protein.

$$
\mathrm{TCT}=\mathrm{RT}+\mathrm{RUT}
$$

Where: $\mathrm{TCT}(\mathrm{min} /$ day $)=$ total chewing time; RT (hour/day) is the rumination time; $\mathrm{TSF}=$ time spent feeding every day (hour/day).

These and other variables obtained in this experiment were obtained according to the methodology described by Bürger et al. (2000).

The data were submitted to a normality analysis using the PROC UNIVARIATE command of the SAS 9.4 program (SAS Institute Inc., Cary, NC, USA). Behavioral data were analyzed using the SAS 9.4 MIXED procedure.

The data of physiological parameters, ruminal and frontal heat emission, were analyzed by repeated measurement over time using the MIXED procedure of SAS 9.4. The covariate matrix used for each variable was the one that presented the lowest Bayesian information criterion (BIC).

In both cases, the model included treatment as a fixed effect and the stall as a random effect as described below:

$$
Y i j=\mu+C i+B j+e i j
$$

Where: $Y i j=$ analyzed variable, $\mu=$ general mean, $C i=$ safflower level, $B j=$ stall effect and $e i j=$ random error.

The data were submitted to analysis of linear and quadratic polynomial contrasts, considering a significant effect when $P<0.05$.

\section{RESULTS AND DISCUSSIONS}

There was no effect of the inclusion $(\mathrm{P}>$ $0.05)$ of safflower on the temperature obtained on the forehead, skin, eye, and flank of the animals, with averages $26.48 ; 28.75 ; 29.82$, and $25.40^{\circ} \mathrm{C}$ (Table 2). Even without showing effects, Salles et al. (2016), cited that through thermography, it is possible to identify small changes in temperature and allow monitoring with greater precision.

\begin{tabular}{|c|c|c|c|c|c|c|c|}
\hline \multirow{2}{*}{ Item } & \multicolumn{3}{|c|}{ Inclusion levels (\%) } & \multirow[b]{2}{*}{ Average } & \multirow{2}{*}{ EP } & \multicolumn{2}{|c|}{ P-value } \\
\hline & 0.0 & 7.5 & 15 & & & $\mathrm{~L}$ & Q \\
\hline Forehead & 27.41 & 25.90 & 26.14 & 26.48 & 0.781 & 0.255 & 0.366 \\
\hline Skin & 28.34 & 28.74 & 29.17 & 28.75 & 0.665 & 0.380 & 0.971 \\
\hline Eye & 30.37 & 29.28 & 29.82 & 29.82 & 0,501 & 0.446 & 0.188 \\
\hline Left flank & 24.62 & 25.15 & 26.43 & 25.40 & 1.320 & 0.336 & 0.816 \\
\hline
\end{tabular}

Table 2. Infrared thermography $\left({ }^{\circ} \mathrm{C}\right)$ of lambs fed with increasing levels of safflower grains

$\mathrm{EP}=$ standard error of the mean; $\mathrm{L}=$ linear effect and $\mathrm{Q}=$ quadratic

Biologically, the temperature of the eyeball decreased by $3.6 \%$ and that of the forehead by $5.5 \%$ for the inclusion of $7.5 \%$ safflower. The effectiveness of infrared thermography in this region is due to capillarity and sympathetic innervation, which respond quickly to changes in blood flow (Salles et al., 2016; Stewart et al., 2008). Salles et al. (2016) highlighted that the forehead 
temperature is the component with the highest correlation to the animals' physiological responses; being a good place for detecting diseases and febrile states; but when changes in the diets offered to the animals are not intense, mistakes can be made.

One of the main forms of heat dissipation is through the skin; the way they generate the body temperature varies from 28.40 to $36.88^{\circ} \mathrm{C}$ (Webster and Johnson, 1964). The animals' skin temperature ranged from 28.34 to 29.17 - $\mathrm{C}$, showing that the animals were possibly not subjected to thermal stress. The animals were exposed to an average THI of 56.84; lambs in an environment with THI $<82$ are in thermal comfort
(Rathwa et al., 2017). The type of installation may also have influenced, Martello et al (2016), highlights that animals housed in tropical conditions and covered installations, of the commercial type, have greater variations.

The increase in rectal temperature is an indicator of thermal stress by animals (Rathwa, et al. 2017). Salles et al. (2016), highlight that the forehead and flank thermography have a high correlation with the animals' rectal temperature; in this study, the rectal temperature decreased quadratically with the addition of safflower $(\mathrm{P}=0.048)$ (Table 3$)$, without changing the respiration rate $(\mathrm{P}$ $=0.529$ ).

Table 3. Physiological parameters of lambs fed with increasing levels of safflower grains

\begin{tabular}{lcccccccc}
\hline \multirow{2}{*}{ Variável } & \multicolumn{3}{c}{ Inclusion levels $(\%)$} & & \multirow{2}{*}{ SEM } & \multicolumn{3}{c}{ P-value } \\
\cline { 2 - 3 } & 0.0 & 7.5 & 15 & Average & & L & Q \\
\hline $\begin{array}{l}\text { Respiratory rate } \\
\text { (breath/minute) }\end{array}$ & 47.20 & 43.00 & 41.63 & 43.94 & 6.234 & 0.529 & 0.853 \\
$\begin{array}{l}\text { Rectal temperature } \\
\left({ }^{\circ} \mathrm{C}\right)\end{array}$ & 39.19 & 39.56 & 39.08 & 39.28 & 0.089 & 0.358 & 0.048 \\
\hline
\end{tabular}

The heat dissipation pathway through breathing is very important in lambs (Marai et al., 2007). In systems of animals confined in a tropical climate, animals may suffer from thermal stress and increase the respiration rate to decrease heat production. Thus, the use of oilseeds in these situations can help reduce the heat caused during food digestion by producing less heat than carbohydrates (Doreau and Chilliard, 1997). Safflower seed has 27 to $30 \% \mathrm{EE}$ in its composition (Gecgel et al., 2007). However, in the present study, the use of safflower did not decrease the lambs breathing rate. The average respiration rate was 43.9. Despite the decrease in the inclusion of safflower seed in the respiration rate around $9.6 \%$, a statistical effect was not detected, possibly due to the large variation around the average. The basal respiration rate in lambs varies from 36 to 48 beats/me (Hales and Brown, 1974), reaching $300 \mathrm{mov} / \mathrm{min}$ in stressed animals (Terrill and Slee, 1991). In the present study, the variation was 41.6 to 47.2 beats/me for maximum safflower inclusion and control treatment, respectively.

The rumen temperature increased by $6.84 \%$, including $15 \%$ safflower in the diet. Diets with higher concentrations of NDF produce higher metabolic heat than diets with high amounts of non-fibrous carbohydrates, this is due to the activities of rumination and digestion, which did not occur for this study (Table 3). In ruminants, the digestion of fibrous 
carbohydrates has as its final products short-chain fatty acids (acetate in greater proportion); higher concentrations of carbon dioxide, methane, and heat, when compared to non-fibrous carbohydrates; with this, infrared thermography can improve the feed efficiency of animals based on measurements in the distal room (Montanholi et al. 2009). Meat production becomes more efficient with less heat loss and methane production, therefore in animals with the lowest body surface temperatures (McManus et al. 2016).
The animals showed a similarity between feeding and rumination time and idle time, which was related to the intake of dry matter, which did not affect the inclusion of safflower in the diet (Table 4). Marques et al. (2005), point out that animals in collective pens have less physical space available, spending their time moving around the pen and in exploratory activities, or fighting for the leadership of the group, with little time left.

Table 3. Ingestive behavior of lambs fed increasing levels of safflower grains

\begin{tabular}{lccccccc}
\hline \multirow{2}{*}{ Variables (hour/day) } & \multicolumn{3}{c}{ Inclusion levels (\%) } & & \multirow{2}{*}{ SEM } & \multicolumn{2}{c}{$P$-value } \\
\cline { 2 - 4 } \cline { 7 - 9 } & 0.0 & 7.5 & 15 & Average & & L & Q \\
\hline Food & 3.28 & 3.11 & 3.11 & 3.17 & 0.408 & 0.495 & 0.692 \\
Idleness & 12.10 & 12.22 & 12.10 & 12.14 & 1.137 & 0.998 & 0.827 \\
Rumination & 8.63 & 8.67 & 8.80 & 8.70 & 1.010 & 0.774 & 0.935 \\
\hline
\end{tabular}

Table 4. Dry matter and NDF consumption and feed and rumination efficiency, number and time spent feeding lambs fed with increasing levels of safflower grains

\begin{tabular}{|c|c|c|c|c|c|c|c|}
\hline \multirow{2}{*}{ Variables } & \multicolumn{3}{|c|}{$\begin{array}{c}\text { Inclusion Levels } \\
(\%)\end{array}$} & \multirow[b]{2}{*}{$\begin{array}{c}\text { Averag } \\
\mathrm{e}\end{array}$} & \multirow{2}{*}{ EP } & \multicolumn{2}{|c|}{$P$-value } \\
\hline & 0.0 & 7.5 & 15 & & & $\mathrm{~L}$ & Q \\
\hline DMI, kg/day & 1.09 & 1.21 & 1.04 & 1.11 & $\begin{array}{c}0.14 \\
8\end{array}$ & $\begin{array}{c}0.50 \\
2\end{array}$ & $\begin{array}{c}0.08 \\
8\end{array}$ \\
\hline INDF, kg/day & 0.28 & 0.35 & 0.33 & 0.32 & $\begin{array}{c}0.04 \\
2\end{array}$ & $\begin{array}{c}0.10 \\
1\end{array}$ & $\begin{array}{c}0.08 \\
0\end{array}$ \\
\hline IFDM (kg DM ingested/hour) & 0.34 & 0.39 & 0.34 & 0.36 & $\begin{array}{c}0.06 \\
1\end{array}$ & $\begin{array}{c}0.97 \\
4\end{array}$ & $\begin{array}{c}0.11 \\
7\end{array}$ \\
\hline RUDM (kg DM ruminated/hour) & 0.13 & 0.14 & 0.12 & 0.13 & $\begin{array}{c}0.02 \\
5\end{array}$ & $\begin{array}{c}0.48 \\
6\end{array}$ & $\begin{array}{c}0.28 \\
1\end{array}$ \\
\hline INDFap (kg NDF ap ingested/hour) & 0.09 & 0.11 & 0.11 & 0.10 & $\begin{array}{c}0.01 \\
7\end{array}$ & $\begin{array}{c}0.07 \\
1\end{array}$ & $\begin{array}{c}0.11 \\
1\end{array}$ \\
\hline $\begin{array}{l}\text { RUFDN (kg NDF ap } \\
\text { ruminated/hour) }\end{array}$ & 0.03 & 0.04 & 0.04 & 0.04 & $\begin{array}{c}0.00 \\
7\end{array}$ & $\begin{array}{c}0.35 \\
1\end{array}$ & $\begin{array}{c}0.26 \\
5\end{array}$ \\
\hline Nali (n\%/day) & 10.33 & 9.17 & 9.33 & 9.61 & $\begin{array}{c}3.19 \\
8\end{array}$ & $\begin{array}{c}0.59 \\
6\end{array}$ & $\begin{array}{c}0.68 \\
2\end{array}$ \\
\hline Tali (mim/n food) & 20.35 & 21.82 & 21.96 & 21.37 & $\begin{array}{c}6.26 \\
1\end{array}$ & $\begin{array}{c}0.66 \\
3\end{array}$ & $\begin{array}{c}0.83 \\
5\end{array}$ \\
\hline
\end{tabular}


Rumination is affected by the concentration and physical type of dietary fiber. Despite the increase in NDF in diets, there was no increase in rumination $(\mathrm{P}>0.05)$. The fiber content and the physical form of the diet are the main factors that affect the rumination time and intake (Van Soest, 1994); however, with the grinding of safflower grains for the supply of animals, the particle sizes between diets were similar. Carvalho et al, (2004), highlights that the particle size can interfere in the time spent for ingestion, rumination, and leisure.

The voluntary consumption of DM is regulated by two main mechanisms in ruminants: the physical and physiological mechanisms. Thus, the effect of each mechanism on the intake of DM will depend on each one with different temporal effects (Allen, 2000). Although the diet that contained 15\% safflower increased the ether extract content of the diet, this increase was not enough to change the animals' intake pattern, due to the energy of the diets being similar between treatments. The present study hypothesizes that the addition of safflower in the diets of confined lambs would reduce the emission of rumen heat and physiological parameters, such as respiration rate, rectal and skin temperature, and may affect ingestive behavior by increasing the concentration of NDF. However, the low replacement of corn $(9.2 \%)$ by safflower in experimental diets may not have been sufficient to support the hypothesis of the present study.

The increase in energy from the diet increases the flow of propionate to the liver during meals, causing satiety and interruption of consumption to occur
(Allen, 2000), as well as the dietary EE level. However, in the present study, the concentration of EE did not exceed $80 \mathrm{~g}$ of $E E$ that may cause a reduction in $\mathrm{CDM}$ in confined animals (Palmquist, 2006), showing that the inclusion of safflower and as a consequence of $\mathrm{EE}$ did not reduce the consumption of animals, as well as the feeding time.

The inclusion of safflower did not alter DM intake, DM intake efficiency and $\mathrm{DM}$ rumination $(\mathrm{P}>0.05)$. The NDF feeding efficiency (Table 4) showed an increasing linear effect for the inclusion of safflower $(P=0.071)$, without changing the rumination efficiency. Macome et al. (2012), highlighted that diets with high levels of NDF alter the rumination efficiency, reflecting the need to process ruminal digest. The diets in this study showed low concentrations of NDF, an average of $25.45 \%$ (Table 1 ), lower values to increase digestive efficiency, a fact observed in the efficiency of rumination.

The low efficiency of rumination possibly occurred due to the physical form of the diet resulting from the grinding of the grains, which did not affect on the time of feeding and rumination. The low levels of NDF in the diet associated with the consumption of DM compensate for the lower efficiency of rumination (Ramos et al., 2016). In this context, the number of visits to the trough and the feeding time at each visit was not influenced by the inclusion of safflower. There was also no effect of the addition of safflower on the variables MMnb, MMtb, TMT, NBR, and MMnd $(\mathrm{P}>0.05)$ (Table 5).

As with feeding, rumination, and leisure time, the inclusion of safflower did not promote any change in the behavior spent on chewing ruminal cakes. This 
lack of effect of safflower may be related to the small change in the physical and chemical properties of the diets. The parameters related to the rumen cake that reaches the mouth may be influenced by the rate of ingestion and particle size, roughage: concentrate, type of forage, the concentration of non-forage fibe, and the processing used (Yansari et al., 2004). The lack of effect of the inclusion of safflower grain on MMnb, MMtb, TMT, NBR, and MMnd possibly occurs due to the lack of effectiveness of the NDF to cause rumination. Thus, the effectiveness of the fiber increases the time of feeding, chewing and rumination (Zebeli ali et al., 2015), as well as the concentration of NDF in the diet, can change the pattern of rumination (Salfer et al., 2018).

Table 5. Number of chews per ruminal cake, time spent per ruminal cake, total chewing time, number of cakes, and number of chews per day, of lambs fed with increasing levels of safflower grains.

\begin{tabular}{|c|c|c|c|c|c|c|}
\hline \multirow{2}{*}{ Variables } & \multicolumn{3}{|c|}{ Inclusion levels (\%) } & \multirow{2}{*}{ SEM } & \multicolumn{2}{|c|}{ Contrast, P-value } \\
\hline & 0.0 & 7.5 & 15 & & $\mathrm{~L}$ & Q \\
\hline $\mathrm{NRbl}\left(\mathrm{n}^{\circ}\right)$ & 64,14 & 66,58 & 57,37 & 9,608 & 0,241 & 0,243 \\
\hline NRtm (seg/cake) & 36,04 & 38,39 & 35,21 & 4,252 & 0,741 & 0,213 \\
\hline TMT (hours) & 11,903 & 11,776 & 11,901 & 1,137 & 0,998 & 0,827 \\
\hline NBR (nday) & 865 & 826 & 924 & 176 & 0,566 & 0,449 \\
\hline MMnd (n\%/day) & 54623 & 54228 & 51441 & 6164 & 0,385 & 0,703 \\
\hline
\end{tabular}

NRbl: number of chewing per ruminal cake; NRtm: chewing time by rumen cake; TMT: total chewing time; NBR: cake number; MMnd: number of chews per day.

Safflower does not affect the parameters of the ingestive and physiological behavior of confined lambs and the inclusion of up to $15 \%$ safflower can be used without harmful effects on animals. Only the rectal temperature was influenced by the inclusion of safflower and further studies should be conducted to determine the maximum level of inclusion. Infrared thermography does not detect milder changes in temperature in confined lambs and if used, the evaluation must be careful to consider the evaluated region.

\section{ACKNOWLEDGMENT}

The Coordination for the Improvement of Higher Education Personnel CAPES; The Federal University of Grande Dourados, for financial support and scholarships. To State University of
Maringá; Support Foundation for the Development of Education, Science and Technology of the State of Mato Grosso do Sul (FUNDECT) and the National Council for Scientific and Technological Development - CNPq; for funding part of this work. Besides, the authors express thanks to teacher Luís Carlos Ferreira de Souza, for the donation of the Safflower grains, used.

\section{REFERENCES}

Allen, M. S. Effects of diet on shortterm regulation of feed intake by lactating dairy cattle. Journal of Dairy Science, Champaign, v. 83, n. 7, p. 1598-1624, 2000.

Araki, H.M.C, Gandra, J.R., Oliveira, E.R., Takiya, C.S., Goes, R.H.T.B., Gabriel, A.M.A., Rodrigues, G.C. G., 
Gandra, E. R. S., Pereira, T.L., Damiani, J., Batista, J.D.O. Effects of Chitosan and Whole Raw Soybeans on Feeding Behavior and Heat Losses of Jersey Heifers., Iranian Journal of Applied Animal Science, n. 8, v.3, p397-405. 2018.

Beauchemin, K. A.; McGinn, S. M.; Benchaar, C.; Holtshausen, L., Crushed sunflower, flax, or canola seeds in lactating dairy cow diets: effects on methane production, rumen fermentation, and milk production. Journal of Dairy Science, 92 (5): 2118-2127, 2009.

Bürger, P.J., Pereira, J.C., Coelho Da Silva, J.F., Valadares Filho, S.C.; Queiroz, A.C.; Cecon, P.R.; Monteira, H.C.F. Consumo e digestibilidades aparentes total e parcial em bezerros holandeses alimentados com dietas contendo diferentes níveis de concentrado. Revista Brasileira de Zootecnia, v.29, n.1, p.206-214, 2000.

Carvalho, G.G.P., Pires, A.J.V., Silva, F.F., Veloso, C.M., Silva, R.R., Silva, H.G.O., Bonomo, P. e Mendonça, S.S. Comportamento ingestivo de cabras leiteiras alimentadas com farelo de cacau ou torta de dendê. Pesquisa Agropecuária Brasileira, v. 39, n. 9 p.919-925. 2004.

Chacur, M.G.M.; Souza, C.D.; Andrade, I.B., Bastos, G.P., Deak, F.L.G.; Souza, M.G.R.; Cornacini, G.F.; Marques Junior, A.P. Aplicações da termografia por infravermelho na reprodução animal e bem-estar em animais domésticos e silvestres. Revista Brasileira de Reprodução Animal, Belo Horizonte, v.40, n.3, p.88-94, 2016.
Coşge, B.; Gürbüz, B.; Kiralan, M. Oil

Content and Fatty Acid Composition of Some Safflower (Carthamus tinctorius L.) Varieties Sown in Spring and Winter. International Journal of Natural and Engineering Sciences, v. 1, n. 3, p.11-15, 2007.

Doreau, M. and Chilliard, Y.

Digestion and metabolism of dietary fat in farm animals. British Journal of Nutrition. v.78, n.1, p. S15-S35, 1997.

Eustáquio Filho, A.; Carvalho, G. G. P.; Pires, A. J. V.; Silva, R. R.; Santos, P. E. F.; Murta, R. M.; and Pereira, F. M. Ingestive Behavior of Lambs Confined in Individual and Group Stalls. Asian-Australasian Journal of Animal Science. v. 27, n.2, p. 284-289. 2014.

doi: 10.5713/ajas.2013.13212

Fischer, V., Deswysen, A. G.; Dèspres, L.; Dutilleul, P.; Lobato, J. F. P Ingestive behavior nycterohemeral patterns of dairy cows, at the beginning and at the end of lactation, fed corn silage based. Revista Brasileira de Zootecnia. v.27, n.5. p.362-369. 1998.

Gecgel, U., Demirci, M., Esendal, E.; Tasan, M. Fatty Acid Composition of the Oil from Developing Seeds of Different Varieties of Safflower (Carthamus tinctorius L.). Journal of the American Oil Chemists' Society. v. 84, p. 47-54, 2007. https://doi.org/10.1007/s11746-0061007-3

HALES, J. R. S.; BROWN, G. D. Net energetic and thermoregulatory efficiency during panting in the 
sheep. Comp. Biochemical Physiology, [S.1.], v. 49, p. 413-422, 1974.

Macome, F.M., Oliveira, R.L., Araujo, G.G.L., Barbosa, L.P., Carvalho, G.G.P., Garcez Neto, A.F. e Silva, T.M. Respostas De Ingestão e Fisiológicas de Cordeiros Alimentados Com Torta de Dendê (Elaeis Guineensis). Archivos de Zootecnia, v.61, n.235, p.335-342. 2012.

Mader, T. L.; Davis, M. S.; BrownBrandl, T. M. Environmental factors influencing heat stress in feedlot cattle. Journal of Animal Science, v.84, p.712-719. 2006.

Marai, I.F.M.; ElDarawany, A.A.; Fadiel, A.; AbdelHafez, M.A.M. Physiological traits as affected by heat stress in sheep - a review. Small Ruminant Research., v.71, p. 1-12. 2007.

Marques, J. A., D. Maggioni, and J. J. S. Abrahao. The behavior of young bulls in confinement housed separately or in a group. Archivos Latinoamericanos de Produccion. Animal, v.13, p.97-102. 2005.

Martello, L.S., Da Luz, S.S., Gomes, R.C., Corte, R.S.R.P., Leme, P.R. Infrared thermography as a tool to evaluate body surface temperature and its relationship with feed efficiency in Bos indicus cattle in tropical conditions. International Journal of. Biometeorology, v.60, p. 173-181. 2016. http://dx.doi.org/10.1007/s00484015-1015-9.

McManus, C., Tanure, C. B., Peripolli, V., Seixas, L., Fischer, V., Gabbi, A. M., Costa, J. B. G. Infrared thermography in animal production: An overview. Computers and Electronics in Agriculture, v. 123, p.10-16. 2016. doi:10.1016/j.compag.2016.01.027

Montanholi, Y.R., Swanson, K.C., Schenkel, F.S., Mcbride, B.W., Caldwell, T.R., Miller, S.P., On the determination of residual feed intake and associations of infrared thermography with efficiency and ultrasound traits in beef bulls.

Livestock Science. v.125, n. 1, p.2230. 2009.

http://dx.doi.org/10.1016/j.livsci.2009.0 2.022 .

National Research Council (NRC).

Nutrient requirements of small ruminants. Washington, DC: National Academy Press. 2007. 362p.

Palmquist D.L. Milk Fat: Origin of Fatty Acids and Influence of Nutritional Factors Thereon. In: Fox P.F., McSweeney P.L.H. (eds) Advanced Dairy Chemistry Volume 2 Lipids. Springer, Boston, MA. 2006 https://doi.org/10.1007/0-387-288139_2

Polli, V. A.; Restle, R.; Senna, D. B.; Almeida, S. R. A. De. Aspectos relativos à ruminação de bovinos e bubalinos em regime de confinamento. Revista Brasileira de Zootecnia, v. 25, n. 5, p. 987-993, 1996.

Ramos, A.F.O.; Pinho, B.D.; Lourenço Junior, J.B.; Silva, A.G.M.; Faturi, C.; Martorano, L.G.; Manno, M.C.; Lima, K.R.S.; Sousa, L.F. Ingestive behavior of sheep fed Brazil nut cake in the diet. Semina: Ciências Agrárias, v. 37, n. 4, p. 2259-2268, 2016. 
Rathwa SD, Vasava AA, Pathan MM, Madhira SP, Patel YG, Pande AM. Effect of season on physiological, biochemical, hormonal, and oxidative stress parameters of indigenous sheep. Vet World, v.10, n.6, p. 650654. 2017. doi:10.14202/vetworld.2017.650-654

Roberto, J.V.B.; Souza, B.B. Utilização da termografia de infravermelho na medicina veterinária e na produção animal. Journal of Animal Behavior Biometeorology, v.2, n.3, p.73-84. 2014.

Salfer I.J.; Morelli M.C.; Ying Y.; Allen M.S.; Harvatine K.J. The effects of source and concentration of dietary fiber, starch, and fatty acids on the daily patterns of feed intake, rumination, and rumen $\mathrm{pH}$ in dairy cows. Journal of Dairy Science. v.101, n. 12, p.1091110921. 2018.

Salles, M. S. V.; da Silva, S. C.; Salles, F. A.; Roma, L. C. J. R.; El Faro, L.; Bustos Mac Lean, P. A.; Lins de Oliveira, C. E.; Martello, L. S. Mapping the body surface temperature of cattle by infrared thermography.

Journal of Thermal Biology, v. 62, p. 63-69, 2016.

Sniffen, C. J., O'Connor, J. D., Van Soest, P. J. Fox, D. G., \& Russell, J. B. Net carbohydrate and protein system for evaluation cattle diets. II. Carbohydrate and protein availability. Journal of Animal Science, v.70, n.11, p.35623577. 1992. doi: $10.2527 / 1992.70113562 x$

Stewart, M., Stafford, K.J., Dowling, S.K., Schaefer, A.L., Webster, J.R. Eye temperature and heart rate variability of calves disbudded with or without local anesthetic. Physiology. Behavior. v.93, p.789-797. 2008.

Terrill, C. E.; Slee, J. Breed differences in adaptation of sheep. In: MAIJALA, K. Genetic resources of pigs, sheep, and goat. Amsterdam: Elsevier, 1991. p. 195-233.

Van Soest, P.J. Nutritional ecology of the ruminant. Cornell University Press. Ithaca. 476 pp. 1994.

WEBSTER, M. E. D., \& JOHNSON, K. G. (1964). Distribution of Temperature in the Skin of Sheep exposed to Moderate Environments. Nature, 201(4915), 208209.

Yansari, A. T.; Valizadeh, R.; Naserian, A.; Christense, D. A.; Yu, P.; Shahroodi, E. F. Effects of Alfalfa Particle Size and Specific Gravity on Chewing Activity, Digestibility, and Performance of Holstein Dairy Cows. Journal of Dairy Science, v. 87, n. 11, p. 3912-3924, 2004.

Zebeli Q.; Ghareeb K.; Metzler-Zebeli B.U. Besenfelder, U. Nutrition, rumen health and inflammation in the transition period and their role on overall health and fertility in dairy cows. Research in Veterinary Science. v. 103, n.12, p. 126-136. 2015. https://doi.org/10.1016/j.rvsc.2015.09.0 20 